\title{
DIAS MATHEMATICAL SYMPOSIUM: FORTY YEARS OLD
}

Fiche bliain ag fás, fiche bliain ag bláthú

\author{
J. N. Flavin
}

\section{Introduction}

It is perhaps of some interest to recall that the first DIAS Mathematical Symposium took place forty years ago (at the time of writing). This article recalls the Symposium held (at 64 Merrion Square) on 17th, 18th December 1958, and its genesis. It is based on documentary evidence and on the (inevitably faulty) recollections of a (then!) youthful and passive participant.

\section{Genesis}

As to the genesis of the Symposium/a, the possibility of holding such was discussed at a meeting of Irish participants at the International Congress of Mathematicians held in Edinburgh in August 1958. An invitation was somehow issued to these participants (by J. L. Synge?) and the meeting took place one evening in a room at Edinburgh University, Professor Synge being in the chair. Issues discussed included the need for such, the format, who would be prepared to give talks, funding from DIAS (which J. L. Synge felt would be forthcoming from its Board) and from the university institutions (which never eventuated). To the author's recollection, the participants were primarily, and perhaps exclusively, from the Republic, and hardly exceeded twenty or so in number. 


\section{Symposium Programme}

WeDNESDAY, 17 DECEMBER 1958:

2.30-3.30 : MGR P. DE BRÚN:

Non-Euclidean conic sections, treated as sections of the right circular cone.

3.30-4.00 : Discussion.

4.00-4.30 : COFFEE BREAK.

4.30-5.00 : Previews

(10 minutes each - see Programme Notes):

A) E. F. FAHY:

Asymmetrical ageing (clock paradoxes in relativity).

B) V. G. HART:

Approximate solution of the biharmonic equation.

C) Rev. R. E. Ingram:

Seismic investigation of faults.

D) D. JudGe:

Parity and its conservation.

E) D. KeEFE:

Some aspects of positive and negative heavy mesons.

Thursday, 18 December 1958:

9.30-10.30 : Prof. C. Lanczos:

History of unified field theories in general relativity.

10.30-11.00 : DisCuSSION.

11.00-11.30 : COFFEE BREAK.

11.30-12.30 : PREVIEWS

(10 minutes each - see Programme Notes):

F) Prof. P. B. Kennedy:

Some unsolved problems in classical analysis.

G) Prof. C. Lanczos:

Linear operators and function spaces.

H) Prof. M. A. MacConaill:

Application of matrix methods to the study of the organization of the nervous system.

I) Rev. Prof. J. R. McConnell:

Theory of anti-nucleons. 
J) Rev. J. J. McMahon:

Convex surfaces in potential theory.

2.30-3.30 : Prof. P. B. KenNedy:

The average rate of growth of certain regular functions.

$3.30-4.00$ : DisCUSSION.

4.00-4.30 : COFFEE BREAK.

4.30-5.30 : FinAL MEETING:

Agenda:

1) To decide dates for next symposium.

2) To decide by vote on the basis of previews (or otherwise) what three papers to hear at the next Symposium.

3) To decide how to use in future the two hours devoted to previews in the present programme.

4) To discuss general suggestions about the organization of Symposia.

\section{Notes on Contributors}

[More space is given to people who are less likely to be known to the likely readership, and for no other reason.]

Mgr P. de Brún: Polymath and President UCG ('45-'59); President of Council of DIAS ('40-'60); Professor of Mathematics and Mathematical Physics, Maynooth ('14-'45); doctoral student of E. Picard at Paris. He began his lecture with the remark "I'm like a Bishop throwing in the ball" (a common practice at GAA matches then). Deceased.

C. Lanczos: Well known universalist, Senior Professor School of Theoretical Physics, DIAS ('54-'68). Deceased.

P. B. Kennedy: Prof. of Math. UCC ('56-'63), Professor at University of York ('63-'66); died 1966. Well known classical analyst and inspiring teacher.

E. F. Fahy: Professor, Physics Dept. UCC (-'87); perhaps best attender (other than DIAS members) at Symposia during their first 25 years. Chairman, Board of School of Cosmic Physics DIAS, '90-'95.

V. G. Hart: Lecturer, Math. Physics, UCC ('54-'66), subsequently at Math. Dept. Univ. of Brisbane (Professor '85-). Research with 
J. L. Synge at DIAS ('52-'54) on the hypercircle method (essentially an elegant geometrical formulation of what subsequently became known as the finite element method). Research work in elasticity.

R. E. Ingram SJ: Jesuit lecturer at the Math. Dept. UCD - an algebraist with an interest in elasticity/seismology. Acted as seismologist at the seismic observatory at Rathfarnham. Edited (with H. Halberstam) Hamilton's papers (Vol. 3). Deceased.

D. Judge: Well known Professor at Math. Physics Dept. UCD and quantum theorist.

Denis Keefe: Then at Physics Dept. UCD where he worked on particle physics and cosmic rays; had earlier been at Physics Dept. Bristol. Subsequently at Physics Dept., Univ. of California at Berkeley. Atomic physicist of international reputation. Deceased.

M. A. MacConaill: (Another) polymath and Professor of Anatomy UCC ('42-'73). His many mathematical interests included the mechanics of joints: exotic material - like formulae from lubrication theory - was often included in his anatomy lectures for medical students. Deceased.

J. R. M ${ }^{\mathrm{C}}$ Connell: Succeeded P. de Brún as Professor at Maynooth; well known Senior Professor ('68-'88) at STP of DIAS. Member, Pontifical Academy of Sciences 1990-.

J. M'Mahon: Lecturer ('54-'60) at Maynooth, subsequently Professor of Mathematics there until the early seventies. Scholar at DIAS ('50-'52), working with J. L. Synge on hypercircle method (see V. G. Hart, above). Deceased. [See Obituary, by J. R. Timoney, IMS Newsletter, No. 6, Dec. 1982.]

\section{Participants at First Meeting}

The participants as conveyed by the list of signatures were as follows (to conserve space, brief institutional affiliation is given if recorded, or otherwise known; otherwise town etc. recorded):

DIAS: J. L. Synge, J. D. Strathdee, C. B. Mast, C. Lanczos, H. Zorski, A. Das, T. Takahashi, G. Papini, R. H. W. Johnston, 
M. O'Connell, M. A. Shankit, K. Imaeda, E. R. Wills (not all from Theoretical Physics).

Dunsink: S. McKenna, M. J. Smyth.

Maynooth: G. Mc Greevy, J. McMahon, J. Mcconnell, C. Ryan.

QUB: Hans Schneider.

TCD: L. Bass, T. S. Broderick, D. J. Simms, F. J. O'Connor.

UCC: M. A. MacConaill, J. Flavin, R. Scott, P. J. Donohoe, E. C. Dillon, E. F. Fahy, P. M. Quinlan, P. B. Kennedy, V. Hart, S. O'Shea.

UCD: A. Montwill, D. Keefe, J. R. Timoney, John Kennedy, R. E. Ingram SJ, P. Dolan, D. Judge, P. A. Heelan SJ, M. Rice.

UCG: P. B. Caulfield, S. de Róiste, M. J. Newell, S. Tobin, V. Flanagan, P. de Brún.

Other: Vivion de Valera, B. Scaife, J. W. Forde (all Dublin), L. Grimley SJ (Rathfarnham), J. G. Barrett (Univ. of Cincinnati), C. J. Gillman (Shannon), P. J. Walsh (Antrim).

\section{Closure}

It is appropriate to acknowledge and thank the School of Theoretical Physics, DIAS for the great service that it has provided to the Irish mathematical community, over a forty year period, in organizing and financing a twice yearly mathematical symposium.

\section{Acknowledgement}

The author wishes to thank D.Ó Mathúna, John Duggan, John Lewis (all DIAS), David Judge (UCD) for their assistance. He also thanks Martin Meere (NUIG) for processing the manuscript.

\section{James N. Flavin}

Mathematical Physics Department

National University of Ireland

Galway 